\title{
Revisiting the Scopes Trial: Young-Earth Creationism, Creation Science, and the Evangelical Denial of Climate Change
}

\author{
K. L. Marshall
}

New College, University of Edinburgh, Edinburgh EH1 2LX, UK; 1836759@sms.ed.ac.uk

\begin{abstract}
In the century since the Scopes Trial, one of the most influential dogmas to shape American evangelicalism has been that of young-earth creationism. This article explains why, with its arm of "creation science," young-earth creationism is a significant factor in evangelicals' widespread denial of anthropogenic climate change. Young-earth creationism has become closely intertwined with doctrines such as the Bible's divine authority and the Imago Dei, as well as with social issues such as abortion and euthanasia. Addressing this aspect of the environmental crisis among evangelicals will require a re-orientation of biblical authority so as to approach social issues through a hermeneutic that is able to acknowledge the reality and imminent threat of climate change.
\end{abstract}

Citation: Marshall, K. L. 2021

Revisiting the Scopes Trial:

Keywords: evangelicalism; creation science; young-earth creationism; climate change; Answers in Genesis; biblical literalism; biblical authority; Noahic flood; dispensational theology; fundamentalism

Young-Earth Creationism, Creation Science, and the Evangelical Denial of Climate Change. Religions 12: 133. https://doi.org/10.3390/rel12020133

Academic Editors: Randall Balmer and Edward Blum

Received: 25 January 2021

Accepted: 12 February 2021

Published: 20 February 2021

Publisher's Note: MDPI stays neutral with regard to jurisdictional claims in published maps and institutional affiliations.

\section{Introduction}

The 1925 Scopes "Monkey" Trial is often referenced as a metonymy for American Protestantism's fundamentalist-modernist controversy that erupted in the years following World War I. William Jennings Bryan, the lawyer and politician who argued in favor of biblical creationism ${ }^{1}$ - in keeping with his literal understanding of the narratives in Genesis 1 and Genesis 2-was vindicated when the judge ruled that high school biology teacher John Scopes had indeed broken the law by teaching Darwinian evolution in a public school. Clarence Darrow, Scopes' defense attorney, argued not so much for Scopes' innocence as he did for an allegorical reading of the creation account and keeping the Bible in the field of theology, not history and science. Though the fundamentalist-modernist controversy of the 1920s was much larger than the Scopes Trial, the legacy of the trial remains perhaps the most enduring aspect of the controversy. Rather than looking at the controversy writ large and the Scopes Trial as representative of the controversy, I wish to focus specifically on the legacy of the trial in the rise of a field called "creation science."

Creation science ${ }^{2}$, a field which looks for scientific evidence that the earth was created in a manner consistent with the Genesis account, is taught almost exclusively in the vein of young-earth creationism (YEC), the belief that the earth is less than 10,000 years old and that the geological formations that we see today are the result of the Noahic flood of Genesis 6. While Darwinian evolution, particularly social Darwinism, was the primary target of Bryan at the Scopes Trial, one of the ramifications of YEC is with regard to oil and climate change; if the earth is only a few thousand years old, then oil could not have been created over the course of millions of years. The fact that what mainstream science says

1 Bryan argued for six days of creation, in keeping with the Genesis account; while there was a nascent creation science at the time of the Scopes Trial in keeping with young-earth creationism, creationism had not yet fragmented into the dogma about young-earth creationism and old-earth creationism that exists today. He opposed the ethical implications of evolution, particularly social Darwinism, but was willing to acknowledge the possibility of an old earth, provided there was sufficient scientific evidence.

2 In the 1990s, some creationists began to promote the idea of Intelligent Design (ID) in what they saw as a move away from creationism, as ID's proponents claim that it does not hinge on the Genesis narrative. Because legal cases have ruled that ID is an attempt to teach creationism, this article does not distinguish between ID and creation science. See (Numbers 2006) for a detailed approach to the relationship between creation science and ID. 
about the origin of oil conflicts with the foundational tenet of YEC lends itself to the belief that burning fossil fuels does not have the negative environmental impact that mainstream scientists claim.

Creation science, along with the belief that mainstream science cannot be trusted and that the burning of fossil fuels is not harmful, has since become normative in conservative fundamentalist and evangelical circles. In an era plagued by environmental crises, many of these Protestant Christians have come to deny anthropogenic climate change and support their views by pointing to the conclusions produced by creation science, which claims to have its basis in the divine authority of the Bible. ${ }^{3}$ I will argue that what creation science actually does is enact a false pillar on which biblical authority ${ }^{4}$ should rest, because according to creation science's own claim, if YEC and its scientific arm are incorrect, then the entire Bible cannot be trusted.

\section{Old-Earth Creationism and the Scopes Trial}

Popular portrayals of the infamous trial, such as in the 1960 movie Inherit the Wind (which changed the names of the characters involved but otherwise attempted to recreate the trial), have attempted to cast those who favored biblical creationism as backwards, anti-intellectual bumpkins. Bryan had spent the few years prior campaigning for laws banning the teaching of evolution, claiming not only that the theory undermined the Genesis creation account and the unique status of humans as being created in the image of God but also that social Darwinism would harm the grassroots masses that he had long championed, ${ }^{5}$ those who rejected his views saw him as being opposed to reason and scientific progress, and at the Scopes Trial, the journalist H.L. Mencken viciously derided him and all fundamentalists in the national press. However, the literalist position that denounces evolution is only one of several ways that conservative Protestants have grappled with the Genesis account. Another view is old-earth creationism, and for much of the nineteenth and early twentieth centuries, this understanding was taught at one of the most prestigious Protestant institutions in the United States, Princeton Seminary.

The Princeton Theology, as Old Princeton's approach to the Bible became known, supported a view that reconciled the Bible with science through lenses such as the day-age theory (which suggests that each of the "days" in Genesis 1 and 2 is not a 24-h day but rather an age of thousands or even millions of years) and gap theory (which suggests a gap of millions of years, perhaps more, between Genesis 1:2 and 1:3). These theories, known as old-earth creationism, support a model in which the earth is as old as geologists suggest and that this old age is not irreconcilable with the Genesis account. Charles Hodge (17971878), the most prolific of the Old Princetonians, was not alone in his belief that theology and science, both properly understood, mutually reinforce each other; he supported a view - taught at nearby Princeton College - which asserted that the "first day" of the Genesis narrative corresponded with the earth's formation over millions of years out of a nebula of gas and dust. Hodge conceded that modern geology — which saw the earth as millions, if not billions, of years old — did not necessarily contradict the Bible, though he notably did reject Darwinian evolution on the grounds that it was essentially atheism. ${ }^{6}$ Shortly before the Scopes Trial, Benjamin Breckenridge Warfield (1851-1921), the last of the Old Princetonians, promoted the Bible's divine authority alongside evolution, albeit with a very nuanced approach to Darwin's theory. ${ }^{7}$

\footnotetext{
3 See (Stephens and Giberson 2011) for exposition and analysis of conservative evangelicalism's "experts" who reject secular accounts of history, science, psychology, et cetera in favor of a strict adherence to the Bible as the source of all truth.

4 In speaking of the Bible's divine authority, I am referring to "authority" in the more etymological understanding regarding its authorship, as divine authorship leads to the Bible's normative value (its "authority" in a more traditional sense) in evangelical faith and praxis. In contrast, speaking of biblical inerrancy as normative for evangelicals has a political charge related to The Fundamentals, and that charge is beyond the scope of this article (except in direct reference to The Fundamentals).

5 (Willis 1990, p. 101).

(Gutjahr 2011).

(Livingstone and Noll 2000).
} 
Ultimately, the old-earth view promoted by the Princeton Theology became Bryan's undoing at the Scopes Trial. ${ }^{8}$ Clarence Darrow, the defense attorney who wanted antievolutionary laws to be struck down, called Bryan to the stand as an expert witness on the Bible. For hours, Darrow grilled Bryan on questions relating to the authority of the Bible as the Word of God until Bryan suggested old-earth creationism, that perhaps creation happened over thousands or even millions of years rather than six 24-h days. Darrow saw this interpretation as incompatible with the literalist view inherent in the Tennessee law that prohibited teaching evolution in public schools, and many of his supporters agreed. The result was possibly the most Pyrrhic victory in the history of American Protestantism: the fundamentalists won the trial but lost the respect of the public; they also lost the bigger war of the fundamentalist-modernist controversy. ${ }^{9}$

Perhaps the most enduring legacy of the Scopes Trial, in terms of the development of creation science in the decades to come, was that old-earth creationism was not consistent with an approach to the Bible as the divinely inspired Word of God. The outcome was two dichotomous options, Darwinian evolution and young-earth creationism, and many conservative Protestants came to see YEC as the only theologically viable approach to the Bible. ${ }^{10}$ While there is not a complete consensus among evangelicals, in the marketplace of ideas presented by mainstream evangelical thought, the old-earth model received a mortal wound at the Scopes Trial. The severity of the wound would be revealed nearly a half-century later.

\section{Early Fundamentalism and Old-Earth Creationism}

During the nineteenth century, two strands emerged within American Protestantism that, leading up to the fundamentalist-modernist controversy, would be considered "fundamentalist." In its original context of early-twentieth-century American Protestantism, "fundamentalist" referred to a reactionary movement that sought to preserve the Bible's divine authority against the rise of historical-critical exegesis. ${ }^{11}$ The term derived from a series of essays entitled The Fundamentals, published between 1910 and 1915, which affirmed a high view of the Bible, a rejection of Darwinism, and the significance of the "fundamentals"; the fundamentalists were those who affirmed the fundamentals of the faith, points that included biblical inerrancy and the virgin birth. Yet there was a militancy to this movement, if more latent at first, that scholars now see as a primary characteristic of fundamentalist movements; during the fundamentalist-modernist controversy of the 1920s, the fundamentalists were seen as those who were ready to do battle for the Lord. Particularly since the 1970s, both scholars and the mass media have applied the term "fundamentalism" to describe religious movements that exhibit militancy in their defense of scriptures against critical forms of exegesis. Fundamentalism is often also associated with millenarian beliefs about the impending end of the world and appearance of a utopian world in its place, as well as a separatism that sees co-religionists who are not fundamentalists as apostates. ${ }^{12}$

The first of these two strands of fundamentalism, Old-School Presbyterianism, may be better understood as evangelical rather than fundamentalist, at least in a contemporary sense, and had Princeton Seminary as its intellectual base. While much of the Princeton

Bryan's anti-evolution crusade in the years following World War I stood in contrast to the contemporary teachings of Warfield and his Old Princeton predecessors, yet some details of Bryan's life strongly suggest that he would have had some familiarity with Old Princeton's attempts to reconcile science and the Bible. Bryan was an Old-School Presbyterian, and the intellectual center of Old-School Presbyterianism, prior to the fundamentalistmodernist controversy, was Princeton Seminary. He served as Secretary of State from 1912 until 1915 under President Woodrow Wilson; Wilson himself had served as president of Princeton University and, though a much more modernist Presbyterian, had established relationships with leading figures of Princeton Seminary.

9 Fundamentalism continued to thrive in the years following the Scopes Trial, though it largely left the public sphere as fundamentalists developed enclave communities where they could practice their faith without public derision.

10 As will be shown below, liberal and some conservative evangelicals have tended towards views that are more consistent with mainstream science, including old-earth creationism. However, their voices are in the minority and have nowhere near the influence as popular YEC organizations, such as Answers in Genesis. See (Stephens and Giberson 2011).

11 (Marty 2015).

12 (Marty 2015). 
Theology—such as the rejection of historical-critical exegesis—was a reaction to the crises of modernity exhibited during the nineteenth and early twentieth centuries, those associated with Old Princeton did not demonstrate the militancy, millenarianism, and separatism often associated with fundamentalism. ${ }^{13}$ With some exceptions, Old-School Presbyterianism did not consider YEC to be a theological necessity in order to uphold a high view of the Bible; Hodge accepted old-earth geology, and Warfield went so far as to concede to evolution.

The other strand, better understood as "fundamentalist" in a modern context because of its millenarian beliefs and separatist ecclesiology, consisted of the dispensationalists, who crossed denominational lines (several, including James Hall Brookes and his protégé, Cyrus Scofield, were Old-School Presbyterians, and many were Baptists) and also found their being outside of denominations. Dispensational theology is a form of premillennialism that sees biblical prophecies as foretelling the imminent return of Christ to rapture the church into heaven as a precedent to seven years of God's wrath, known as the Great Tribulation. With the Rapture, God's purposes in history will shift from His spiritual people, the church, to His earthly people, Israel; the Great Tribulation will conclude with the Second Coming heralding the beginning of the Messianic Kingdom or Millennial Reign, what dispensationalists consider to be the Millennium spoken of in Revelation 20. For 1000 years, Christ will reign from a throne in Jerusalem - the restoration of Israel's Davidic kingdomnot as the Savior of the world, as he was in the First Coming, but as the Messiah of the Jews. In addition to dispensational theology's inherent millenarian beliefs about the end of the world (the Great Tribulation) and its restoration (the Millennial Reign), the faction was notably more militant and more separatist than the Old-School Presbyterians. Though many dispensationalists rejected the willingness of the more militant J. Frank Norris, a dispensationalist pastor, to shoot and kill another person (arguably in self-defense), they embraced a separatism in which they were to "come out from among them and be ye separate" (2 Corinthians 6:17, King James Version). Well before the Scopes Trial but more so after it, the dispensationalists had their own networks of churches and Bible institutes, where they could study the Bible together while awaiting the Rapture.

Old Princeton was decidedly not dispensationalist, but many dispensationalists studied there because the seminary maintained a high view of the Bible against the historicalcritical exegesis that was, in the fundamentalist mindset, chipping away at biblical authority. ${ }^{14}$ At least until the Scopes Trial, the dispensationalist movement leaned heavily towards the old-earth creationism taught at Old Princeton, and the 1909 edition of the Scofield Reference Bible - which made dispensational theology accessible through its commentary-taught gap theory. ${ }^{15}$ Despite the influence of the Princeton Theology on the dispensationalist approach to the Bible, the two strands of thought remained largely distinct from one another. In the wake of the Scopes Trial and subsequent reorganization of Princeton Seminary, the Princeton Theology—along with Hodge's and Warfield's efforts to reconcile science and the Bible, albeit a much-diminished view of old-earth creationismbecame absorbed into evangelicalism, ${ }^{16}$ while the dispensationalists retained a separatist identity to protect their approach to the Bible.

\section{Creation Science and the Evangelical Social Conscience}

While fundamentalism can be considered a subset of evangelicalism, evangelicalism and fundamentalism should be understood independently of each other. There are many different ways of defining what evangelicalism is, and here I will present two key com-

13 (Noll 1983, pp. 11-24; Ahlstrom 2004, p. 806).

14 (Ahlstrom 2004, pp. 812-15). James Hall Brookes, one of the leaders of the dispensational movement of the late nineteenth centuries, had previously attended Princeton Seminary prior to converting to dispensationalism. He brought the Princeton Theology into the dispensational movement, particularly through his mentorship of Cyrus Scofield (editor of the Scofield Reference Bible) and leadership of the Niagara Bible Conference, a center of dispensational thought.

15 Bishop Ussher's chronology, which posited an exact date for the creation of the world about 6000 years ago, was also popular among conservative Protestants, including but not limited to the Old-School Presbyterians and the dispensationalists (Ahlstrom 2004, p. 811).

16 (Noll 1983, p.11). 
ponents. The first is that evangelicalism is the largest and the longest-running reform movement in American history, dating back to about the Great Awakening of the 1730s and 1740s. The second is that this reform movement is embedded in an approach to the Bible that sees it as the divinely inspired and authoritative Word of God. When evangelicals have addressed social issues-from abolition to urban poverty to temperance to civil rights to abortion to climate justice- they have done so out of deep convictions regarding how they should apply the Word of God to their lives and to society. This reforming impulse that stems from convictions about the Bible is what I refer to as the evangelical social conscience.

When a post-Scopes YEC and creation science emerged, they immediately took on the millenarianism of dispensational theology. As this section will show, the scientists and theologians behind creation science saw their interpretation of Genesis as exemplifying the sovereignty of God and His righteousness in executing judgment on wickedness, from the Noahic flood to the impending end of the world. Yet creation science quickly migrated from its fundamentalist origins and became firmly embedded within evangelicalism; as such, the millenarianism of YEC became part of the evangelical social conscience. While evangelicals were developing an environmentally conscious posture during the late 1960s and early 1970s, one issue in particular, abortion, would cause YEC and creation science to become part of the evangelical hermeneutic regarding both the Bible and public policy. ${ }^{17}$ With the fervor of the newfound Religious Right, YEC would have the must success not in the push for creation science in public schools nor in the pro-life crusade, but in anti-environmental legislation that promoted drilling for fossil fuels.

A generation after the Scopes Trial, dispensationalists spearheaded the development of creation science to show the superiority of the YEC approach that championed strict biblical literalism. The field of creation science has roots that stretch back at least to the 1800s, but it began to emerge in its modern form with the 1961 publication of The Genesis Flood by John Whitcomb and Henry Morris. ${ }^{18}$ As the name of the book suggests, the Noahic flood of Genesis 6 is critical to creation science, as the flood was responsible for geological formations that appear to be millions of years old. The Genesis Flood was the first book to successfully promote the idea that if the Noahic flood had truly happened, in accordance with the Genesis narrative, then its implications for geology would certainly be tremendous. The introduction to the book opens with the words,

The question of the historicity and the character of the Genesis Flood is no mere academic issue of interest to a small handful of scientists and theologians. If a worldwide flood actually destroyed the entire antediluvian human population, as well as all land animals, except those preserved in a special Ark constructed by Noah (as a plain reading of the Biblical record would lead one to believe), then its historical and scientific implications are tremendous. ${ }^{19}$

The introduction goes on to claim that, because the Noahic flood was a divine judgment on the entire world, it foreshadows the judgment yet to come, the Great Tribulation. The book goes on to say,

For that universal catastrophe [the flood] speaks plainly and eloquently concerning the sovereignty of God in the affairs of men and in the processes of nature. Furthermore, it warns prophetically of a judgment yet to come, when the sovereign God shall again intervene in terrestrial events, putting down all human

17 There is considerable disagreement as to how significant the issue of legalized abortion was in the development of the Religious Right. However, abortion became one of the galvanizing features that pulled together conservative Protestants (and many non-Protestants, as well) across denominational lines and into a voting bloc.

18 In 1923, George McCready Price published The New Geology, which suggested many of the same ideas as The Genesis Flood regarding flood geology and the age of the earth. However, Price was a Seventh-Day Adventist who lacked both scientific and theological training (Morris' background as a hydraulic engineer and Whitcomb's as a seminary professor gave them credentials that Price lacked), and his book did not have the influence among evangelicals that Morris and Whitcomb's did.

19 (Whitcomb and Morris 1961, p. xix). 
sin and rebellion and bringing to final fruition His age-long plan of creation and redemption. ${ }^{20}$

As such, denying a literal interpretation of the Noahic flood as a global event-an interpretation that includes seeing the flood as the basis for the geological formations seen today-is a denial of the sovereignty of God over the earth and His divine authority to judge sin and wickedness. ${ }^{21}$

The authors of The Genesis Flood were dispensationalists, and their interpretation not only initiated the development of a post-Scopes YEC but also caused many dispensationalists to see YEC as essential to a dispensational worldview. Morris and Whitcomb showed that gap theory is theologically unsound, particularly with a dispensational hermeneutic, because it adds an extra age to history that is not elucidated in the Bible; the strict literalism of YEC, which sees only what is written as authoritative and does not seek to extrapolate based on what is not written, was more consistent with a dispensational hermeneutic. ${ }^{22}$ In keeping with the theological development of YEC as critical to a dispensational worldview, the 1967 edition of the Scofield Reference Bible dismissed gap theory, which previous editions had supported, in favor of YEC.

For this first generation of creation scientists, the smoking gun of the inadequacy of old-earth geology and Darwinian evolution was the fossil record, particularly the alleged "missing link(s)" that would show continuity between lower-developed lifeforms and higher-developed lifeforms. According to Morris and Whitcomb in The Genesis Flood, there is no missing link or gap in the fossil record; rather, the Noahic flood created ideal conditions for the reasonably complete array of the earth's past flora and fauna to be preserved as fossils. As such, the Noahic flood explains the completeness of the fossil record and leaves no room for any missing link(s). Similarly, the Noahic flood accounts for the presence of oil deposits in the earth's crust, as the immense pressure created by the water rapidly converted dead organic material into hydrocarbons. ${ }^{23}$ For young-earth creationists who read The Genesis Flood, the young-earth model answered geological and biological challenges better than an old-earth model, and YEC was vindicated as superior to mainstream science. Meanwhile, the influence of The Genesis Flood went far beyond dispensational circles; while mainstream scientists dismissed the book, it sold hundreds of thousands of copies to both fundamentalists and evangelicals.

A decade after the publication of The Genesis Flood, in 1972, Francis Schaeffer published a book entitled Genesis in Space and Time. Though Schaeffer himself was not a dispensationalist and focused more on a critique of culture than on millenarian views, Genesis in Space and Time built on the hermeneutical argument staged by Morris and Whitcomb regarding the necessity of a young earth. According to Schaeffer, an epistemology rooted in ancient Jewish thought will necessarily interpret the creation story as literally true in a scientific and historical sense, and our understanding of the life of Jesus and the very nature of the Trinity rests on this interpretation; one cannot hold to a mythological or allegorical interpretation of Genesis while holding to a literal understanding of the life and teachings of Jesus. All of the events recorded in Genesis, including the creation account, must have occurred within space and time in order for the Bible to be consistent with itself. ${ }^{24}$

While Schaeffer did not delve too deeply into the developing field of creation science, he did dismiss old-earth creation views that attempt to reconcile the Bible with mainstream science. In Genesis in Space and Time, he posited that though some Christians had become excited about the possibility of the Big Bang-it pointed to an exact moment of creation,

20 (Whitcomb and Morris 1961, p. xix).

21 Ironically, though the authors of The Genesis Flood believed that YEC was the only way to interpret a divinely authoritative Bible, they looked to Warfield - who supported evolution—-to underpin their approach (see Whitcomb and Morris 1961, p. xx).

22 In arguing against old-earth creationism, Morris and Whitcomb ironically seem to have agreed with Clarence Darrow, an agnostic, and dissented with the views of Hodge and Warfield. This approach is characteristic of fundamentalism, which sees theological moderates as more dangerous (due to their apostatizing compromise) than those outside the religion.

23 (Whitcomb and Morris 1961, pp. 123, 265-67, 429-37).

24 (Schaeffer 1972, pp. 13-31). 
as opposed to a static universe that has always existed-such an event was inconsistent with the personality of the Triune God; theories of the Big Bang and evolution had to be dismissed because they are unable to answer humanity's deeper spiritual need of knowing and being known by a personal God who created the heavens and the earth ${ }^{25}$ Indeed, many of Schaeffer's writings centered on the uniqueness of men and women as created in the image of God (Genesis 1:27) and how the Imago Dei translates into a worldview that values human life, most notably in regard to abortion and euthanasia.

At the same time that YEC was filtering into the evangelical hermeneutic, in 1967, Lynn White wrote a paper entitled "The Historic Roots of our Ecologic Crisis," in which he laid much of the blame for an impending environmental catastrophe at the feet of Christians, due to dominionist views that led to overconsumption of natural resources. Assuming an old-earth geology (White was not party to debates about the Bible and the age of the earth), the paper helped spark an environmental focus on the social conscience of American evangelicals during the late 1960s and early 1970s. ${ }^{26}$ The nascent environmentalism of evangelicals was cautious, as leaders feared Christians would lose their sense of spirituality if they focused too much on protecting nature, which was ultimately material. However, evangelicals began encouraging the development of renewable energy sources, which would be less harmful than drilling for and burning fossil fuels, and some promoted vegetarianism as a way of mitigating overconsumption. Environmentalism became one of the many values that evangelicals placed on their social agenda during the 1960s and 1970s, alongside racial inequity, poverty, hunger, and child welfare; Schaeffer critiqued capitalism and materialism while encouraging a more harmonious relationship with nature. ${ }^{27}$ Yet one issue in particular, abortion, became central to the evangelical social conscience; in the thought of Schaeffer, who was becoming immensely popular among evangelicals, the pro-life cause was intrinsically tied to a YEC worldview in which all humans-including the unborn - are created in the Imago Dei.

Schaeffer's opposition to abortion became a galvanizing force that, by the early 1980s, came to dominate the newly formed voting bloc known as the Religious Right. Though the names Jerry Falwell, Tim LaHaye (who, along with Henry Morris, co-founded Christian Heritage College and its Institute for Creation Research), Pat Robertson, and Paul Weyrich would become ubiquitous with the Religious Right, Francis Schaeffer was one of the key people in introducing abortion as a concern that Christian voters should engage. With Schaeffer's view that opposing abortion was a natural outcome of a worldview rooted in the Imago Dei and a young-earth approach to the Bible, the Religious Right vehemently protested the teaching of evolution in public schools, often in a manner that seemed reminiscent of William Jennings Bryan's crusade during the 1910s and 1920s. ${ }^{28}$ This time, though, these activists had science-creation science-to support an alternative to evolution as well as to present a superior worldview that valued human life.

The young-earth creationists of the Religious Right never did succeed the way that Bryan did a half-century earlier. Though some school boards adopted YEC textbooks, they were quickly supplanted with science textbooks that taught evolution and old-earth geology. In the many legal challenges that characterized the YEC movement of the 1980s and 1990s, the creationists suffered one defeat after another. ${ }^{29}$ YEC never successfully found its way into public schools (private school and homeschool curriculum often promoted creation science), and the push to end legalized abortion met virtually no success. However,

25 (Schaeffer 1972, pp. 13-31).

26 (Grizzle et al. 1988, pp. 3-27).

27 (Schafer 2013, pp. 72-75).

28 Schaeffer's critique of Western culture presented two dichotomous options: the anti-God approach of secular humanism, which ultimately degraded human life by enabling euthanasia and abortion, and a theo-centric approach that values humans as created in the image of God. This critique became embedded in the Religious Right's approach to YEC. See (Hankins 2008).

29 Benjamin Huskinson (2020) documented the court cases associated with creation science in American Creationism, Creation Science, and Intelligent Design in the Evangelical Market. See also (Moran 2012). 
YEC did find its way into public policy in terms of market de-regulation, particularly regarding the fossil-fuel industry and emissions.

For Jerry Falwell—the dispensationalist pastor who organized the Religious Right's flagship organization, the Moral Majority, in 1979-legislation that attempted to reduce emissions of fossil fuels ran afoul on two grounds. ${ }^{30}$ On one level, these environmental efforts de-legitimized the sanctity of free-market capitalism, what Falwell saw as the economic system endorsed by the Bible. Fortifying capitalism by de-regulating businesses, rather than burdening businesses with environmental regulations, promoted the Imago Dei by allowing people to use the skills and creativity that God had given them. The alternative was communism, the ideology that devalued human life so severely that it led the Soviet government to massacre millions of its own people in the gulag. For Falwell, free-market capitalism, without restrictions such as on the burning of fossil fuels, was ColdWar America's front-line defense against communism and best assurance of a high value of human life. ${ }^{31}$ On another level, acknowledgment of climate change-which scientists were raising alarm bells for in the 1970s and 1980s as something that could occur in the near future-went against the wisdom of YEC and creation science; instead, these concerns fell back on the biases and untruths of mainstream science, which was not based on the Bible. Because of how fossil fuels formed rapidly after the Noahic flood, as opposed to the mainstream claim that they formed over millions of years, burning them poses no environmental threat. Shortly before his death in 2007, Falwell claimed that Americans were being deceived by warnings of climate change and that Christians calling for tougher environmental protections were falling for Satan's scheme of using environmental concerns to distract them from evangelism. For Falwell and like-minded fundamentalists and evangelicals in the Religious Right, the push for environmentalism took Christians away from worshiping the Creator and instead emphasized created things. ${ }^{32}$

During the 1980s heyday of the Religious Right, Falwell had a public friendship with Ronald Reagan; though Reagan was hardly a devotee of YEC and creation science, he did endorse Falwell's push to de-regulate businesses and reduce environmental legislation. Reagan's administration, particularly under Secretary of the Interior James Watt, not only decreased the budget of the Environmental Protection Agency but also eliminated many environmental laws from the past two decades, particularly those that placed environmental-friendly regulations on businesses. The Reagan era also saw markedly increased drilling and burning of fossil fuels; possibly the only legislative successes of YEC during the prime years of the Religious Right were in anti-environmental policies. ${ }^{33}$ This legacy would lay an important foundation for the next generation of YEC apologists.

\section{Young-Earth Creationism and Climate Change}

While some young-earth creationists acknowledge the harm to the climate caused by the burning of fossil fuels, creation science generally suggests that such claims are false. Building on the thesis of Morris and Whitcomb in The Genesis Flood, creation scientists, particularly Ken Ham at Answers in Genesis, say that claims about global warming ignore the geological implications of the Noahic flood and the overall age of the earth; through Answers in Genesis, which began in 1994, and its \$27 million Creation Museum that opened in 2007, Ham's YEC-centered approach to the Bible and science has become normative among evangelicals and fundamentalists. For Ham and others in the generation of youngearth creationists that succeeded Morris, Whitcomb, Schaeffer, and Falwell, denying climate change seems to be a theological necessity that they are called to defend with science.

30 Very notably, Falwell became most known for his crusade against abortion, and he claimed that his motivation for political activism was the 1973 Roe $v$ Wade decision. However, he did not preach his first sermon against abortion until five years later, in 1978. While Falwell certainly never condoned abortion and his followers fully rejected it, abortion was likely a secondary issue to him.

31 Jerry Falwell, "The Two Flags in Today's World," preached on July 3, 1983. See also (Falwell 1980, pp. 3-20, 71-83).

32 Jerry Falwell, "Global Warming," preached on 25 February 2007.

33 (Hamblin 2015). 
An article on the Answers in Genesis website, entitled "Global Warming: Fact or Fiction?" says,

If a scientist believes in billions of years of earth history, he will assume, for example, that polar ice needed hundreds of thousands of years to build up over two miles in depth. Scientists who believe in the biblical account of Noah's Flood, on the other hand, believe the ice must have appeared shortly after the Flood. Depending on their assumptions, equally skilled scientists can reach very different conclusions. ${ }^{34}$

As such, any alarmism over rising levels of greenhouse gases in the atmosphere is overstated. In another article, entitled "Climate Change Facts," the author points to the promise that God made in Genesis 8:22 to show that even if there are fluctuations in the earth's temperature, there is no cause for alarm. ${ }^{35}$ The verse reads, "While the earth remains, seedtime and harvest, cold and heat, winter and summer, and day and night shall not cease" (New King James Version). God, in His sovereignty, promised that the patterns and rhythms of nature, by which we live our lives, will continue as He created them; humanity is not powerful enough to overwhelm that promise, and certainly not by burning fossil fuels.

With regard to the development of oil reserves underground, Ham and his colleagues restate the arguments staged by Morris and Whitcomb in The Genesis Flood. According to Answers in Genesis, the Noahic flood, which occurred about 4500 years ago, provided the impetus for the geological formations that appear to be millions, if not billions, of years old; not only was the global deluge responsible for carving out formations such as the Grand Canyon, but it also created conditions for oil and other fossil fuels to be formed fairly rapidly. As such, everything that mainstream scientists have said about fossil fuels is wrong, including their claims that burning fossil fuels is harmful. ${ }^{36}$

Exploring Creation with Biology, a high school textbook written for homeschooled children, also challenges the idea that the climate is warming and that any warming trends are man-made. According to the textbook, though additional carbon dioxide may be coming into the atmosphere because of human activity, natural processes, such as photosynthesis and the dissolution of carbon dioxide into the oceans, are constantly removing carbon dioxide. The textbook goes on to assert that some of the molecules emitted by the burning of fossil fuels deflect sunlight away from the earth, thereby mitigating any potentially warming effect of a buildup of carbon dioxide. As such, any changes in weather patterns that may be occurring today are part of constant fluctuations in the earth's climate, not the result of any anthropogenic activity. ${ }^{37}$

The Discovery Institute, a thinktank that uses the YEC model as its underlying hermeneutic to approaching both the Bible and public policy, has a much broader scope than evolution and geology; its staff sees YEC as necessary for maintaining the values of Western culture. Articles produced by The Discovery Institute consistently compare the values of climate-change proponents with those of Darwinists, one reason being that the terms "evolution" and "climate change" are so vague that they defy clear definition; those who may disagree with the idea of macro-evolution and/or the "survival of the fittest" become falsely categorized with those who deny that any form of micro-evolution can happen. That vagueness leads to gross generalizations between those who deny any climate change ever happens and those who believe that there are natural fluctuations in the temperature of the earth. In the end, both climate change and evolution are conspiracies by the Left to undermine the Christian values that have shaped Western society since

4 "Global Warming: Fact or Fiction?" Answers in Genesis. Undated.

5 "Climate Change Facts," from Answers in Genesis. Undated.

6 Mortenson, Terry. “Noah's Flood: A Historical, Global Catastrophe.” Answers in Genesis. 10 October 2010.

7 (Wile and Durnell 2017, pp. 316-21). 
at least the Reformation. ${ }^{38}$ Articles from The Discovery Institute do appear to be more ideologically charged than their counterparts from Answers in Genesis, which does strive to grapple with scientific data.

These claims do not imply that Christians should not be good stewards of creation; God's covenant with Adam in the Garden of Eden required that he care for the earth, and this mandate has never been overturned. However, creation science consistently teaches that environmental stewardship does not necessitate that fossil fuels should be phased out as an energy source; if they should be phased out, the underlying reason is not because of climate change. Because the scientific arm of young-earth creationism suggests that burning fossil fuels is not harmful, the practice does not fall under the realm of environmental stewardship and does not belong on the evangelical social conscience. ${ }^{39}$

\section{Young-Earth Creationism as a Whole-Bible Hermeneutic}

The insistence among creation-science advocates that anthropogenic climate change is not occurring forces the question of why climate-change denial is such an important topic for creation science. At least part of the answer is that the reality of climate change undermines the YEC understanding of the centrality of the Noahic flood to geology; as such, an acknowledgment of climate change challenges a literal interpretation of Genesis and, by extension, the authority of the entire Bible.

Ken Ham has echoed the arguments initially put forth by Morris, Whitcomb, and Schaeffer regarding the necessity of a literal interpretation that leads to a young-earth narrative. If one is unable to believe that God means what He says-that He created the earth in six literal, 24-h days-then that person is unable to uphold the divine authority of the entire Bible. Evolution represents a completely different religion-atheism, as the Old Princetonian Charles Hodge said a century and a half ago—and any compromise with evolution is a blatant disregard of the Bible as the Word of God. Further, if Christians can call the Genesis account into question, then they can also delegitimize the gospel record of the life of Christ and any other part of the Bible. However, a YEC-based affirmation of the creation account allows one to see that the first few chapters of Genesis contain the answers (the "answers in Genesis" of his organization's name) to many other parts of the Bible; in addition, a creation-affirming hermeneutic answers many of the worldview (as Schaeffer understood worldview) questions evangelicals ask today, such as in regard to abortion, LGBTQ+ rights, and euthanasia. God's intimate involvement with the creation of the first two humans, Adam and Eve, reveals a particularly high calling of humanity as both superior to the animals and of expressing the Imago Dei. Social ills, particularly abortion and pornography, are the result of the church compromising with an old-earth model-even an old-earth creationism model-rather than upholding a literal understanding of the Genesis account. ${ }^{40}$ As such, for Ham among many creationists, YEC is a whole-Bible hermeneutic that sees the first few chapters of Genesis as a litmus test for one's approach to the rest of the scriptures, as well as for one's comprehensive worldview. ${ }^{41}$

To reinforce the idea that YEC is a whole-Bible hermeneutic, Ham claims-in a manner consistent with The Genesis Flood - that if creation science is wrong, then the entire Bible cannot be trusted. While he has stated this view in some of his publications, it is depicted most graphically at his Creation Museum in Petersburg, Kentucky. In a promotional video for the Creation Museum, Ham described his creation-centered worldview; while in the present age scientists claim to have disproven the Bible, the museum shows why one can

38 Jay Richards, “What Do Darwinism and 'Climate Change' Have in Common?” The Discovery Institute. 4 March 2010. See also Jay Richards, “When to Doubt a Scientific 'Consensus'” The Discovery Institute. 16 March 2010.

39 Biola University may stand alone as having a division of creation science while not necessarily denying the imminent danger caused by climate change. Though there is a lack of consensus among staff as to whether or not climate change is being caused by the burning of fossil fuels, Biola has developed several programs that encourage responsible environmental stewardship, including with regard to climate change, in keeping with God's mandate that humans are to care for creation.

40 Journey Through the Creation Museum, directed by Ken Ham. 2012.

41 Zaimov, Stoyan, “Ken Ham Says Believing in 6 Days of Creation Is 'Litmus Test' on Biblical Authority." Christian Post. 16 September 2016. 
believe the history contained within the Bible. Because the history within the Bible is scientifically true-particularly the creation account and Noahic flood-we can trust that the message of the Bible, namely the gospel records of the life of Christ, is true. Throughout the museum, exhibits of biblical characters, such as Adam, Eve, and Noah, are interspersed with exhibits of creation science that show why the biblical accounts are literally correct. ${ }^{42}$ One might note with a sense of irony that, in this view as with the early incursions of Darwinism into American Protestantism, science-creation science-actually becomes the arbiter of the Bible. In the final section, I will expand on this irony and how a superior approach to the Bible's divine authority can resolve it.

As YEC and creation science developed initially in dispensational circles, particularly under Morris and Whitcomb, this approach to the Bible remains a significant feature in a dispensational worldview. In dispensationalism, YEC goes beyond the whole-Bible hermeneutic promoted by Ham, along with the view that burning fossil fuels is not harmful, to show why oil was central to creation and God's plan for the world. The late John Walvoord, among other leading dispensationalist figures from Dallas Theological Seminary, suggested that oil was divinely created by God and placed in particular geographical regions for the purpose of fulfilling biblical prophecies that herald the End Times. ${ }^{43}$ Particularly in his 1974 book Armageddon, Oil, and the Middle East Crisis (which was written in the context of the 1973 OPEC embargo and was revised in 1990 to account for Saddam Hussein's invasion of Kuwait) but also in other publications by professors at Dallas Theological Seminary, Walvoord and his former colleagues have pointed to the massive oil fields in the Middle East, along with the turbulent events that surround the extraction of oil there, as consistent with biblical prophecies regarding Babylon (near modern-day Baghdad, Iraq) and Israel during the End Times.

According to Armageddon, Oil, and the Middle East Crisis, the sheer wealth generated by oil has given Iraq the potential of becoming one of the wealthiest countries in the world, consistent with the wealth of Babylon spoken of in Revelation in what dispensationalists see as End-Times prophecies. Tensions related to oil have further exacerbated the PalestineIsrael conflict, another important component of a dispensational view of history, including future history. Further, with the world's dependence on oil, including the United States' reliance on Middle-Eastern oil, nearly every person on earth has become beholden to the tumultuous events unfolding in the Middle East and will be unable to escape their apocalyptic, prophetic ramifications. With these geopolitics created by oil, Walvoord saw the world as poised for the fulfilment of prophecies about the End Times. ${ }^{44}$

In this eschatological mindset, any relationship between oil and climate change is irrelevant. Dispensational theology's millenarianism teaches that God did not create the present earth to last, and that it will soon end. The new heaven and the new earth, spoken of in Revelation 20 and 21, are what dispensationalists look forward to; until then, the state of the world will progressively deteriorate. Climate change, if it is occurring, may be nothing more than part of that progressive deterioration.

\section{Climate Justice and the Evangelical Social Conscience}

Despite the prevalence of YEC and creation science in evangelical thought, denial of anthropogenic climate change (caused by the burning of fossil fuels rather than by natural processes) is not unanimous among evangelicals. Jim Wallis, the founder of Sojourners, has long been leading a movement of evangelicals who are calling for climate justice as part of fulfilling the biblical mandate to be stewards of creation. ${ }^{45}$ He quotes Isaiah 24:5-6 to show the significance of creation care for Christian faith; the verses read, "The earth lies polluted under its inhabitants; for they have transgressed laws, violated the statues, broken

Journey Through the Creation Museum.

43 There are many different varieties of dispensational theology, and not all dispensationalists agree with the view that oil is the divine resource driving the events of the End Times.

44 (Walvoord 1990, pp. 11-16).

45 Jim Wallis, "An Evangelical Climate Change," in Sojourners Magazine, May 2006. 
the everlasting covenant. Therefore a curse devours the earth, and its inhabitants suffer for their guilt" (NRSV). ${ }^{46}$ The Evangelical Environmental Network works for creation care, including climate justice, out of core beliefs regarding God's reconciliation with the world through Christ and the New Testament's command to love neighbor as self. ${ }^{47}$ Francis Collins, an evangelical who serves as the director of the National Institute of Health, said, "One of my greatest heartaches is that at the present time we are seeing ... serious believers, who are led by some circumstances to believe that they have to defend a literal interpretation of Genesis in order to defend their faith, find themselves contradicting facts that God Almighty has given us the ability to discover." 48 There are many other evangelical individuals and organizations who are advocating for climate justice and finding that their most formidable opponents are actually other evangelicals.

These environmentally conscious evangelicals are not advocating for abortion rightseven though for many evangelicals, the pro-life cause is embedded in YEC, and they implicitly believe that a hermeneutic that opposes YEC cannot sustain the Imago Dei-and consider themselves to be fervently pro-life precisely because they recognize the harm caused by burning fossil fuels. The question that must be raised is, What is the difference between evangelicals who deny anthropogenic climate change and those who advocate for climate justice as part of the pro-life evangelical social conscience? I wish to posit here that the primary difference is not whether evangelicals are looking at mainstream science or creation science. In the evangelical mindset, in which reforms are embedded in an approach to the Bible that sees it as the authoritative Word of God, the primary difference is the approach to this divine authority, specifically whether or not sustaining biblical authority requires a literalist, young-earth approach to Genesis.

\section{Sola Scriptura as a Superior Foundation for Biblical Authority}

Significantly, the initial public denouncement of old-earth creationism did not come from young-earth creationists, as would happen in later years, but from Clarence Darrow, who was agnostic. As such, many of the claims that suggest that old-earth creationism is not theologically viable originated from Darrow's argument against the Princeton Theology rather than from Bryan's defense of biblical creationism. For young-earth creationists, the issue at stake is not so much whether or not the earth is getting warmer but rather the doctrine of the Bible's divine authority and a high value of human life. For many, biblical authority means biblical literalism, that every word of the Bible should be taken at face value; this approach to the Bible is supported by the philosophy of Scottish Common Sense which, as the epistemology for a biblical hermeneutic, suggests that the words of the text can be universally understood outside of their original cultural context. However, the Protestant doctrine of biblical authority did not emerge from the Scottish Enlightenment and its Common-Sense philosophy but rather from the Reformation's central feature of sola scriptura. Rather than arguing whether or not Scottish Common Sense presents a viable means for interpreting the Bible, I wish to conclude by turning to sola scriptura, with an emphasis on Jim Wallis, an evangelical who acknowledges anthropogenic climate change, and how evangelicals can reconceptualize the Bible's divine authority in a manner consistent with the doctrine's origins.

Because Ken Ham's Creation Museum praises Martin Luther as the most significant figure for Christians since the closure of the canon, I will turn to Luther's views to demonstrate why sola scriptura is superior to literalism. Luther himself was a literalist, as were many of his fellow Reformers. Yet he also acknowledged that some biblical passages are better understood allegorically rather than literally, and that an allegorical interpretation does not necessarily undermine the Bible's authority. ${ }^{49}$ What does undermine the Bible's authority is when something other than the Bible becomes a normative counterpart to

46 Jim Wallis, "Climate Change and Creation Care," lecture from Georgetown University's Berkley Center.

47 "Beliefs," from Evangelical Environmental Network website. https://creationcare.org/who-we-are/beliefs.html.

48 “Dr. Francis S. Collins Interview," in PBS Religion E Ethics News Weekly, 21 July 2006.

49 (Hendrix 2010). 
the Bible; hence, the central doctrine of the Reformation was sola scriptura, not biblical literalism. For Luther, the Bible was the norma normans non normata, the norm of norms that cannot be normed; not that the Bible cannot be supported with sound evidence and argumentation (Luther frequently engaged in theological debates), but the most cogent argument and decisive evidence are not determinative of the Bible's divine authority. ${ }^{50}$

In this vein of sola scriptura, even if creation science is scientifically sound, it is theologically unsound because it suggests that the authority of the Bible rests on the reliability of creation science. The Creation Museum visibly displays why creation science is an essential component of biblical authority and why biblical authority collapses apart from the teachings of creation science. Despite Ham's well-intentioned efforts, in this view, the Bible is no longer the norma normans non normata because creation science has effectively become the norm that norms the Bible. This view is theologically incompatible with sola scriptura; young-earth creationism is not necessarily theologically unsound, but creation science as a means of upholding the Bible is.

Sola scriptura is bolstered by the doctrine of solus Christus. For Luther, the scriptures were the manger that holds Christ, and he is the center that holds all of the Bible together. In contrast to this view, a hermeneutic that hinges on the creation narrative in Genesis dethrones Christ in favor of six 24-h days. YEC apologists, particularly those who follow the models of Schaeffer and Ham, posit that a literal reading of Genesis is necessary if the gospel accounts of the life of Christ are to be considered reliable. Yet this approach is the reverse of the doctrine of solus Christus, which teaches that the integrity of the Genesis account-along with the rest of the Bible-hinges on Jesus Christ as the incarnate Word of God. Whether or not creation science is scientifically sound, Schaeffer's and Ham's reliance on the creation account as a whole-Bible hermeneutic is theologically unsound because it places the Genesis narrative, rather than the gospel, at the center of divine revelation. Again, YEC is not necessarily theologically unsound; however, it does not serve as a viable hermeneutic for interpreting all of scripture according to sola scriptura, because the center of scripture must be Christ and Christ alone.

With the doctrines of sola scriptura and solus Christus, the authority and reliability of the Bible do not necessarily depend on a literal reading of the Genesis creation account. Allegorical interpretations of Genesis 1 and 2 can be (but not necessarily are) theologically sound, and the gap theory promoted by Old Princeton maintains theological viability. As such, evangelicals who conceptualize the Bible's divine authority in terms of sola scriptura rather than literalism can acknowledge the reality of climate change and the urgency to act. They do not need creation science in order to believe that the Bible is true, and they can recognize that the Bible does not necessarily disagree with much (though certainly not all) of modern science. Rather, the Bible stands on its own merit, and the fact that burning fossil fuels is causing widespread damage does not undermine biblical authority. For Wallis and many other environmentally conscious evangelicals, faith in the Bible as the inspired Word of God and the centrality of Christ in divine revelation are precisely what motivate the call to end our dependence on fossil fuels. ${ }^{51}$

This hermeneutic of sola scripture that is able to grapple with the environmental crisis places a high value on human life and the Imago Dei. Wallis points to the United Arab Emirates, whose wealth is the product of an oil-based economy, as a slave state that, despite its immense financial resources and ability to routinely host international conferences, severely devalues human life; many of the foreign workers who are employed in the UAE and similar countries live in inhumane conditions that often lead to death. Further, our dependence on oil has led to wars in oil-rich countries such as Iraq; those wars have decimated local cultures and severely impoverished the people. These challenges in oil-rich countries are compounded by climate change, which is affecting the world's poorest people

50 The early fundamentalist movement developed as a reaction against historical-critical exegesis, which has a relationship with sola scriptura that should not be dismissed. However, I wish to posit a means for fundamentalists and evangelicals to recapture the Protestant origins of biblical authority.

51 Wallis, "Climate Change and Creation Care." 
at a much more accelerated rate than those in affluent countries that consume the most oil. Prioritizing the Imago Dei in the evangelical social conscience requires moving away from fossil fuels and developing clean energy sources, which will provide meaningful jobs and empower local economies while also halting climate change (though more certainly needs to be done than moving away from fossil fuels).$^{52}$ Climate justice begins with placing the Imago Dei and the centrality of Christ back at the center of the evangelical social conscience, to empower a hermeneutic that allows evangelicals to address the many ways that dependence on fossil fuels has ravaged the world.

Though the evangelical consensus seems to be that anthropogenic climate change is a fiction of mainstream science (if not an outright conspiracy), a re-evaluation of biblical authority and an examination of the social conscience among environmentally conscious evangelicals reveals a much more nuanced picture. Denial of climate change is by no means necessary in order to sustain biblical authority, and continuing our dependence on fossil fuels does not support a high view of human life and the Imago Dei. Whether or not YEC remains part of the evangelical intellectual framework, the evangelical social conscience requires that this massive reform movement acknowledge and address the imminent reality of climate change.

Funding: This research received no external funding.

Data Availability Statement: Not applicable.

Conflicts of Interest: The author declares no conflict of interest.

\section{References}

Ahlstrom, Sydney. 2004. A Religious History of the American People, 2nd ed. New Haven: Yale University Press, p. 806.

Falwell, Jerry. 1980. Listen, America! New York: Bantam Books, pp. 3-20, 71-83.

Grizzle, Raymond, Paul Rothrock, and Christopher Barrett. 1988. Evangelicals and Environmentalism: Past, Present, and Future. Trinity Journal 19: 3-27.

Gutjahr, Paul. 2011. Charles Hodge: Guardian of American Orthodoxy. Oxford: Oxford University Press, pp. 366-71.

Hamblin, Jacob Darwin. 2015. Ronald Reagan's Environmental Legacy. In A Companion to Ronald Reagan. Edited by Andrew Johns. West Sussex: John Wiley and Sons, pp. 257-74.

Hankins, Barry. 2008. Francis Schaeffer and the Shaping of Evangelical America. Grand Rapids: Eerdmans.

Hendrix, Scott. 2010. Luther: A Very Short Introduction. Oxford: Oxford University Press, pp. 36-46.

Huskinson, Benjamin. 2020. American Creationism, Creation Science, and Intelligent Design in the Evangelical Market. London: Palgrave MacMillan.

Livingstone, David, and Mark Noll. 2000. B.B. Warfield (1851-1921): A Biblical Inerrantist as Evolutionist. Isis 91: 283-304. [PubMed]

Marty, Martin. 2015. Religious Fundamentalism: Cultural Concerns. In International Encyclopedia of the Social and Behavioral Sciences, 2nd ed. Edited by James Wright. London: Elsevier, pp. 396-400.

Moran, Jeffrey. 2012. American Genesis: The Evolution Controversies From Scopes to Creation Science. Oxford: Oxford University Press.

Noll, Mark. 1983. The Princeton Theology, 1812-1921. Grand Rapids: Baker Book House, pp. 11-24.

Numbers, Ronald. 2006. The Creationists: From Scientific Creationism to Intelligent Design. Cambridge: Harvard University Press.

Schaeffer, Francis. 1972. Genesis in Space and Time. Downers Grove: InterVarsity Press, pp. 13-31.

Schafer, Axel. 2013. Countercultural Conservatives: American Evangelicalism from the Postwar Revival to the New Christian Right. Madison: University of Wisconsin Press, pp. 72-75.

Stephens, Randall, and Karl Giberson. 2011. The Anointed: Evangelical Truth in a Secular Age. Cambridge, MA: The Belknap Press of Harvard University.

Walvoord, John. 1990. Armageddon, Oil, and the Middle East Crisis, rev. ed. Grand Rapids: Zondervan Publishing House, pp. 11-16. Whitcomb, John C., and Henry Morris. 1961. The Genesis Flood: The Biblical Record and its Scientific Implications. Phillipsburg: The Presbyterian and Reformed Publishing Company, p. xix.

Wile, Jay, and Marilyn Durnell. 2017. Exploring Creation with Biology, 2nd ed. Anderson: Apologia Educational Ministries, pp. 316-21. Willis, Garry. 1990. Under God: Religion and American Politics. New York: Simon and Schuster, p. 101. 